\title{
Toxicity and Outcome of Intensive Chemotherapy for Acute Lymphoblastic Leukemia Complicated with Turner's Syndrome
}

\author{
Takeshi SaIto, Noriko Usui, Osamu Asai, Shingo Yano, Katsuki SugIYAma, \\ Mamoru HisATOMI, Kyoko UEDA, Nobuaki DoBASHI and Masayuki KoBAYASHI
}

\begin{abstract}
A 17-year-old woman was diagnosed as acute lymphoblastic leukemia (ALL). As she had chromosomal abnor malities of $44, X O, \operatorname{der}(9) t(3 ; 9)(q 11 ; p 13), \operatorname{der}(10 ; 19)(q 10$; p10), del(15)(q15), $-16,-19,+22$ with the presence of ovarian dysplasia and abnormal physical features, a diagnosis of Turner's syndrome was made. She received an induction chemotherapy, which consisted of daunorubicin, cyclophosphamide, vincristine, $L$-asparaginase and prednisolone. Although, severe liver dysfunction was observed, the patient achieved a complete remission (CR) on day 31 following chemotherapy and has maintained CR for more than five years. The recording of such cases may well be of value to clarify toxicity and outcome after chemotherapy for patients with ALL complicated with Turner's syndrome.
\end{abstract}

(Internal Medicine 44: 145-148, 2005)

Key words: Turner's syndrome, acute lymphoblastic leukemia, chemotherapy, liver dysfunction, toxicity

\section{Introduction}

The association between leukemia and chromosomal instability has been widely reported (1). In particular, children with Down's syndrome have a 10 to 20 -fold increase in the risk of developing acute leukemia, which is mainly classified as acute myeloid leukemia (AML) M7 according to the French-American-British (FAB) classification (2). It is well known that these patients occasionally experience severe mucositis and infections by the remission induction and consolidation chemotherapies compared to patients without
Down's syndrome. On the other hand, cases of leukemia that are complicated with Turner's syndrome are extremely rare. Therefore, toxicity and outcome after intensive chemotherapy for patients with acute lymphoblastic leukemia complicated with Turner's syndrome are still unclear.

\section{Case Report}

A 17-year-old woman was admitted to our hospital due to general fatigue in May 1999. A peripheral blood examination revealed pancytopenia and she also presented with neck lymph node enlargement and splenomegaly. The patient's white blood cell count was $3.2 \times 10^{9} / l$ with $23 \%$ blasts, the measured hemoglobin level was $6.6 \mathrm{~g} / \mathrm{dl}$ and the platelet count was $46 \times 10^{9} / l$. In addition, the patient also had elevated serum levels of aspartate aminotransferase (AST) (129 IU/l), alanine aminotransferase (ALT) (209 IU/l), alkaline phosphatase (ALP) (394 IU/l), $\gamma$ GTP (326 IU/l) and T-Bil $(1.8 \mathrm{mg} / \mathrm{dl})$, but neither serum antibodies against HCV nor the HB antigen were detected. The serum level of albumin, cholinesterase, prothrombin time, and fibrinogen were all within normal range. Bone marrow aspiration revealed that $97.7 \%$ of blasts were negative for myeloperoxidase staining. Immunophenotypical analyses also showed that blasts expressed CD10, CD19, CD20, CD34 and HLA-DR but were negative for both CD13 and CD33. Additionally, karyotypical analysis of bone marrow revealed the following abnor malities: 44, XO, der(9)t(3;9)(q11;p13), der(10;19)(q10;p10), $\operatorname{del}(15)(q 15),-16,-19,+22$ in 48/50 cells (Fig. 1) and 45, $\mathrm{XO}$ in $2 / 50$ cells.

The patient was diagnosed as having acute lymphoblastic leukemia (ALL; L2) based upon FAB classifications. In addition, a diagnosis of Turner's syndrome was made, based on the presence of ovarian dysplasia, abnormal physical features (short stature, lack of pubic hair, a shield-like chest) and a

From the Division of Hematology and Oncology, Department of Internal Medicine, Jikei University School of Medicine, Tokyo

Received for publication June 7, 2004; Accepted for publication September 22, 2004

Reprint requests should be addressed to Dr. Takeshi Saito, the Division of Hematology and Oncology, Department of Internal Medicine, Jikei University School of Medicine, 3-25-8 Nishi-shinbashi, Minato-ku, Tokyo 105-8461 


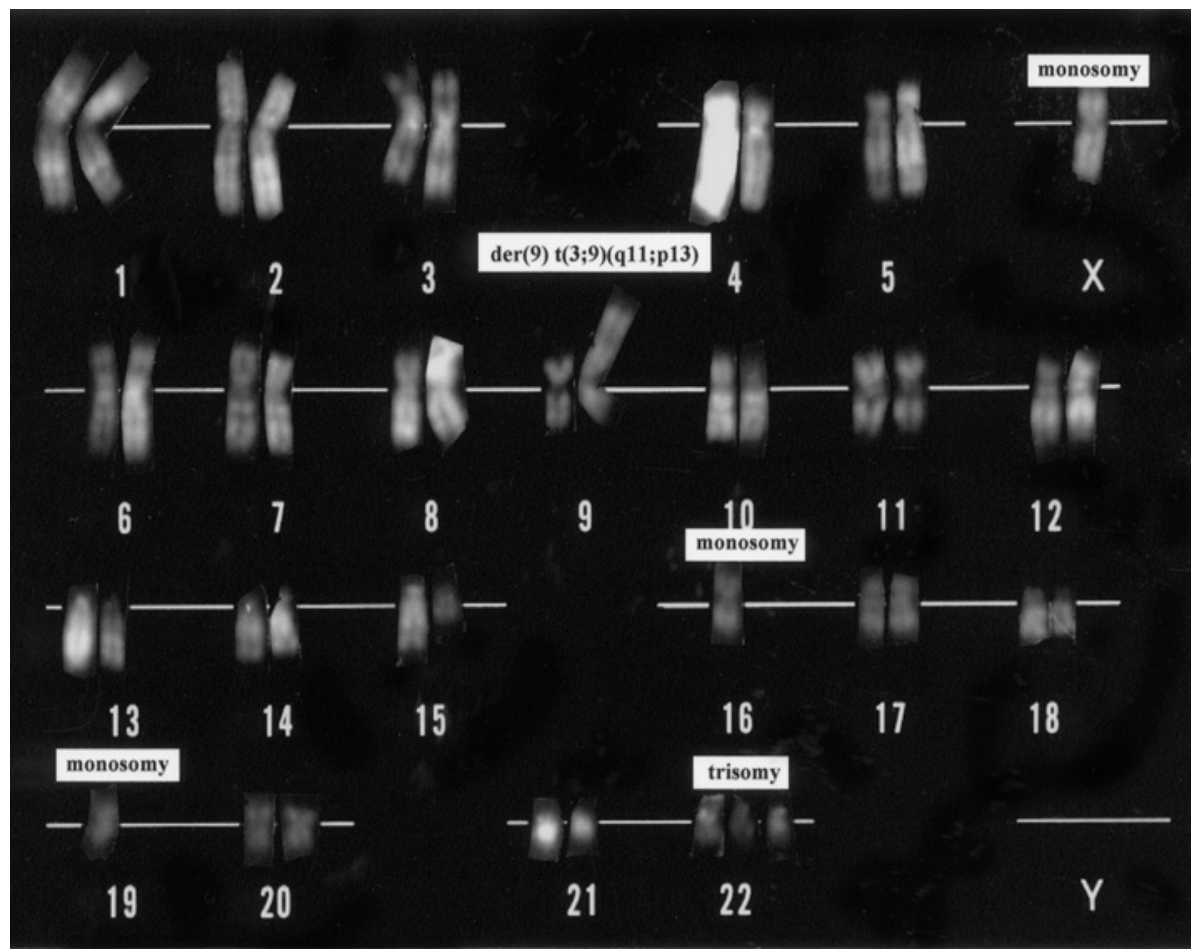

Figure 1. Karyotypical analysis. Karyotypical analysis was performed using the quinacrine mustard method. Karyotypical analysis of bone marrow revealed the following abnormalities: 44, XO, $\operatorname{der}(9) t(3 ; 9)(q 11 ; p 13), \operatorname{der}(10 ; 19)(q 10 ; p 10), \operatorname{del}(15)(q 15),-16$, +22 in $48 / 50$ cells. The other two cells had 45, XO.

marked decrease in plasma estrogen levels whereas an intact adrenal-pituitary axis was evident.

She received an induction chemotherapy consisting of daunorubicin (45 mg/m ${ }^{2}$, days $\left.1-3\right)$, cyclophosphamide $(1,200$ $\mathrm{mg} / \mathrm{m}^{2}$, day 1$)$, vincristine $\left(1.3 \mathrm{mg} / \mathrm{m}^{2}\right.$, days $1,8,15$, and 22$)$, L-asparaginase $\left(3,000 \mathrm{U} / \mathrm{m}^{2}\right.$, days $9,11,13,16,18$, and 20), and prednisolone $\left(60 \mathrm{mg} / \mathrm{m}^{2}\right.$, days $\left.1-14\right)$. On day 17 from the start of chemotherapy, the plasma levels of AST, ALT, ALP, $\gamma \mathrm{GTP}$ and T-Bil elevated to $370 \mathrm{IU} / l, 512 \mathrm{IU} / l, 1,114 \mathrm{IU} / l$, $556 \mathrm{IU} / \mathrm{l}$, and $10.1 \mathrm{mg} / \mathrm{dl}(\mathrm{D}-\mathrm{Bil}=7.4 \mathrm{mg} / \mathrm{dl})$, respectively. The serum levels of albumin, cholinesterase, fibrinogen, and prothrombin time decreased to $2.9 \mathrm{~g} / \mathrm{dl}, 2,194 \mathrm{mU} / \mathrm{ml}, 44$ $\mathrm{mg} / \mathrm{dl}$, and $47 \%$, respectively. We therefore discontinued the administration of L-asparaginase (days 18 and 20) and vincristine (day 22). However, the plasma T-Bil level remained high as $19.6 \mathrm{mg} / \mathrm{dl}$ on day 32 following chemotherapy. Although the plasma T-Bil level recovered to normal range within 2 months, there were sustained elevated plasma levels of AST and ALT for more than 6 months following treatment. In spite of the severe liver dysfunction, the patient attained complete remission (CR) on day 31 after initial chemotherapy and karyotypical analysis at this stage revealed 45 , XO in 20/20 cells. The patient has now maintained CR for more than five years.

\section{Discussion}

Turner's syndrome afflicts approximately 50 per 100,000 females (3) and is characterized by abnormal growth, gonadal dysgenesis and infertility. Turner's syndrome has also been associated with a number of other diseases including diabetes mellitus, reduced bone mineral content and liver dysfunction (4). In addition, higher incidences of neurogenic tumors, gynecological tumors, hepatocellular carcinomas and colon cancers have been observed in individuals suffering from this syndrome (5-8). To our knowledge, the incidence of leukemia development associated with Turner's syndrome is rare, with only two cases of ALL (including the present case), four cases of AML, one case of chronic lymphocytic leukemia and two cases of chronic myeloid leukemia reported to date (9-16) (Table 1).

Takeshita et al (16) have reported that leukemogenesis of CML is dependent upon abnormalities in the sex chromosomes of patients with a $45 \mathrm{XO} / 46 \mathrm{XX}$ mosaic. However, in patients with Turner's syndrome, it is unclear whether monosomy X plays an important role in leukemogenesis. Furthermore, in this case study, the patient had karyotypical abnormalities including $\mathrm{t}(3 ; 9)(\mathrm{q} 11 ; \mathrm{p} 13)$. Although abnormalities at $3 q 11$ have been observed in lymphoid neoplasms (17), this specific translocation has not been reported 
ALL Complicated with Turner's Syndrome

Table 1. Leukemia Complicated with Turner's Syndrome

\begin{tabular}{|c|c|c|c|c|c|c|c|}
\hline \multirow{2}{*}{$\begin{array}{l}\text { Reference No. } \\
\quad \text { (year) }\end{array}$} & \multirow{2}{*}{$\begin{array}{c}\text { Disease } \\
\text { (FAB subtype) }\end{array}$} & \multirow{2}{*}{ Age } & \multirow{2}{*}{$\begin{array}{l}\text { Extramedulary } \\
\text { involvement }\end{array}$} & \multicolumn{2}{|r|}{ Karyotypic analysis of } & \multirow{2}{*}{ Therapy } & \multirow{2}{*}{ Survival } \\
\hline & & & & normal cells & leukemia cells & & \\
\hline $9(1963)$ & $\begin{array}{l}\text { AML } \\
\text { (UE) }\end{array}$ & 64 & - & $45, \mathrm{XO} / 47, \mathrm{XXX}$ & UE & PSL, 6-MP & $\begin{array}{c}\text { DOD } \\
(4 \text { months })\end{array}$ \\
\hline $10(1967)$ & CLL & 62 & UE & $45, \mathrm{XO} / 46, \mathrm{XX}$ & UE & UE & UE \\
\hline $11(1970)$ & $\begin{array}{l}\text { AML } \\
\text { (UE) }\end{array}$ & 13 & Splenomegaly & $45, \mathrm{XO}$ & $45, \mathrm{XO}$ & UE & UE \\
\hline $12(1970)$ & $\begin{array}{l}\text { ALL } \\
\text { (UE) }\end{array}$ & 20 & Splenomegaly & $45, \mathrm{XO}$ & UE & *chemotherapy & $\begin{array}{l}\text { Alive } \\
\text { (6 months }+)\end{array}$ \\
\hline 13 (1982), 14 (1984) & ${ }^{*} \mathrm{CML}$ & 52 & Hepatosplenomegaly & $45, \mathrm{XO} / 46, \mathrm{XX}$ & $45, \mathrm{XO}, \mathrm{t}(9 ; 22)(\mathrm{q} 34 ; \mathrm{q} 11)$ & $\begin{array}{c}\text { HU, 6-MP } \\
\text { \$chemotherapy }\end{array}$ & $\begin{array}{c}\text { Alive } \\
(60 \text { months }+)\end{array}$ \\
\hline $15(1990)$ & $\begin{array}{l}\text { AML } \\
(\mathrm{M} 5 \mathrm{~b})\end{array}$ & 37 & - & $45, \mathrm{XO}$ & $46, X, \mathrm{i}(\mathrm{Xq})$ & DNR, AraC, 6-MP & $\begin{array}{c}\text { Alive } \\
\text { (12 months }+)\end{array}$ \\
\hline $16(1999)$ & CML & 27 & Hepatomegaly & $45, \mathrm{XO} / 46, \mathrm{XX}$ & $45, \mathrm{XO}, \mathrm{t}(9 ; 22)(\mathrm{q} 34 ; \mathrm{q} 11)$ & IFN- $\alpha$ & $\begin{array}{c}\text { Alive } \\
(24 \text { months }+)\end{array}$ \\
\hline our case & $\begin{array}{l}\text { ALL } \\
(\mathrm{L} 2)\end{array}$ & 17 & Splenomegaly, LN & $45, \mathrm{XO}$ & $\begin{array}{c}\text { 44, XO, der(9)t(3;9)(q11;p13), } \\
\operatorname{der}(10 ; 19)(\mathrm{q} 10 ; \mathrm{p} 10), \operatorname{del}(15)(\mathrm{q} 15),-16,-19,+22\end{array}$ & DNR, CPM, VCR, L-asp & $\begin{array}{c}\text { Alive } \\
(60 \text { months }+)\end{array}$ \\
\hline
\end{tabular}

AML: acute myeloid leukemia, UE: unevaluable, CLL: chronic lymphocytic leukemia, ALL: acute lymphoblastic leukemia, CML: chronic myeloid leukemia, "CML: CML patient who developed lymphoid blastic crisis, LN: lymph node enlargement, normal cells: normal cells including buccal mucosal smears, PSL: prednisolone, 6-MP: 6mercaptopurine, *chemotherapy: combination chemotherapy (details are unevaluable), HU: hydroxyurea, ${ }^{\$}$ chemotherapy: L15 protocol, DNR: daunorubicin, AraC: cytosine arabinoside, IFN- $\alpha$ : interferon- $\alpha$, CPM: cyclophosphamide, VCR: vincristine, L-asp: L-asparaginase, DOD: died of disease.

previously. It is also not yet clear whether this translocation is associated with leukemogenesis in patients with Turner's syndrome.

Another important finding of the present case report was that prolonged liver dysfunction was evident following chemotherapy. It had been previously reported that leukemia patients with Down's syndrome experienced severe side effects, including infections and mucositis, following chemotherapy treatment (18). As described in this report, patients with Turner's syndrome occasionally have the complication of liver dysfunction. The major cause of liver dysfunction is drug-related, especially in the cases who received hormonal therapy. In addition, auto-immunity and obesity-related liver dysfunction has also been observed (4). We speculate that the anti-cancer agents, including L-asparaginase and prednisolone, are causal in the present case. Histopathological features of L-asparaginase-induced liver dysfunction show diffuse steatosis (19). On the other hand, sever liver dysfunction caused by intrahepatic cholestasis has been described in cases of Turner' syndrome (20). Because the clinical data of patients with Turner's syndrome who have received chemotherapy is still limited, the correlation between liver dysfunction after receiving chemotherapy and Turner's syndrome remains unclear. Therefore, it is important to be aware that cancer patients with Turner's syndrome may develop severe liver dysfunction following intensive chemotherapy.

Here, we report an extremely rare case of ALL complicated with Turner's syndrome. The reporting of additional cases may well be of value in clarifying whether the underlying genomic instability has a bearing on the occurrence of leukemia. Although, acute leukemia, suffered as a complication of Down's syndrome, has a good prognosis (21), the prognosis for leukemia patients with Turner's syndrome is currently unknown. Her five-year duration of continuing CR is relatively short, however, the outcome of a patient with ALL complicated of Turner's syndrome might not be poor. Further investigation for the differences in cellular drug resistance, pharmacokinetics and the growth advantages of residual leukemic cells is necessary.

\section{References}

1) Robison LL. Down syndrome and leukemia. Leukemia 6: 5-7, 1992.

2) Cairney AE, McKenna R, Arthur DC, Nesbit ME Jr, Woods WG. Acute megakaryoblastic leukemia in children. Br J Haematol 63: 541$554,1986$.

3) Gravholt CH, Juul S, Naeraa RW, Hansen J. Morbidity in Turner syndrome. J Clin Epidemiol 51: 147-158, 1998.

4) Sylven L, Hagenfeldt K, Brondum-Nielson K, von Schoultz B. Middleaged woman with Turner's syndrome. Medical status, hormonal treatment and social life. Acta Endocrinol (Copenh) 125: 359-365, 1991.

5) Wertelecki W, Fraumeni JF Jr, Mulvihill JJ. Nongonadal neoplasia in Turner's syndrome. Cancer 26: 485-488, 1970.

6) Clement PB, Young RH. Atypical polypoid adenomyoma of the uterus associated with Turner's syndrome. A report of three cases, including a review of 'estrogen-associated' endometrial neoplasms and neoplasms associated with Turner's syndrome. Int J Gynecol Pathol 6: 104-113, 1987.

7) Watanabe S, Yamasaki S, Tanae A, Hibi I, Honna T. Three cases of hepatocellular carcinoma among cryptoterone users. Ad hoc Committee on Androcur Users. Lancet 344: 1567-1568, 1994.

8) Hasle H, Olsen JH, Nielsen J, Hansen J, Friedrich U, Tommerup N Occurrence of cancer in women with Turner syndrome. Br J Cancer 73: 1156-1159, 1996.

9) Lewis FJW, Poulding RH, Eastham RD. Acute leukemia in an XO/XXX mosaic. Lancet 2: 306, 1963.

10) Dumars KW, Kitzmiller N, Gaskill C. Cancer, chromosomes and congenital abnormalities. Cancer 20: 1006-1014, 1967.

11) Wertelecki W, Shapiro JR. 45, XO Turner's syndrome and leukaemia. 


\section{SAITO et al}

Lancet 1: 789-790, 1970.

12) Pawliger DF, Barrow M, Noyes WD. Acute leukaemia and Turner's syndrome. Lancet 1: 1345, 1970.

13) Chagatti RS, Bailey RB, Jhanwar SC, Arlin ZA, Clarkson BD. Chronic myelogenous leukemia in the monosomic cell line of a fertile Turner syndrome mosaic (45, X/46, XX). Cancer Genet Cytogenet 5: 215-221, 1982.

14) Dube ID, Arlin ZA, Kalousek DK, Eaves CJ, Eaves AC. Nonclonal hematopoietic progenitor cells detected in long-term marrow cultures from a Turner syndrome mosaic with chronic myeloid leukemia. Blood 64: 1284-1287, 1984.

15) Otokida $K$, Ohira $K$, Ishikawa $M$, et al. A case of Turner syndrome with the karyotype $45, \mathrm{X} / 46, \mathrm{X}, \mathrm{I}(\mathrm{Xq})$ associated with acute monocytic leukemia. Tohoku J Exp Med 161: 19-24, 1990.

16) Takeshita A, Shinjo K, Yamashita M, et al. Extensive cytogenetic studies of clonality following interferon- $\alpha$ therapy in chronic myeloid leukemia occurring in mosaic cells in a patient with Turner syndrome.
Leukemia 13: 1749-1753, 1999.

17) Casato M, Mecucci C, Agnello V, et al. Regression of lymphoproliferative disorder after treatment for hepatitis $\mathrm{C}$ virus infection in a patient with partial trisomy $3, \mathrm{Bcl}-2$ overexpression, and type II cryoglobulinemia. Blood 99: 2259-2261, 2002.

18) Creutzig U, Ritter J, Vormoor J, et al. Myelodysplasia and acute myelogenous leukemia in Down's syndrome; a report of 40 children of the AML-BFM study group. Leukemia 10: 1677-1686, 1996.

19) Sahoo S, Hart J. Histopatological features of L-asparaginase-induced liver disease. Semin Liver Dis 23: 295-299, 2003.

20) Albareda MM, Gallego A, Enriquez J, Rodriguez JL, Webb SM. Biochemical liver abnormalities in Turner's syndrome. Eur J Gastroenterol Hepatol 11: 1039-1039, 1999.

21) Zwaan CM, Kaspers GJL, Pieters R, et al. Different drug sensitivity profiles of acute myeloid and lymphoblastic leukemia and normal peripheral blood mononuclear cells in children with and without Down syndrome. Blood 99: 245-251, 2002. 